\title{
Strategic collective system building to commercialize sustainability innovations
}

\author{
Julia Planko a, b, *, Jacqueline M. Cramer ${ }^{\text {, }}$, Maryse M.H. Chappin ${ }^{\mathrm{b}}$, Marko P. Hekkert ${ }^{\mathrm{b}}$ \\ ${ }^{a}$ HU University of Applied Sciences Utrecht, Daltonlaan 400, 3584 BK Utrecht, The Netherlands \\ b Department of Innovation Studies, Copernicus Institute of Sustainable Development, Utrecht University, Heidelberglaan 2, 3584 CS Utrecht, \\ The Netherlands \\ ${ }^{\mathrm{c}}$ Utrecht Sustainability Institute, Utrecht University, Heidelberglaan 2, 3584 CS Utrecht, The Netherlands
}

\section{A R T I C L E I N F O}

\section{Article history:}

Received 4 July 2014

Received in revised form

8 September 2015

Accepted 23 September 2015

Available online 9 October 2015

\section{Keywords:}

System building

Technological innovation systems

Strategic collaboration

Collective strategy

Sustainability innovation

\begin{abstract}
A B S T R A C T
The implementation of innovative sustainability technologies often requires far-reaching changes of the macro environment in which the innovating firms operate. Strategic management literature demonstrates that the chances of a successful diffusion and adoption of an innovative technology in society are increased if the firms wanting to commercialize this technology collaborate in networks or industry clusters to build a favourable environment for their technology. However, the strategic management literature does not offer advice on how to strategically create this supportive external environment. We fill this gap with complementary insights from the technological innovation systems literature. We introduce the concept of strategic collective system building; this concept describes processes and activities that networks of actors can strategically engage in to collectively build a favourable environment for their innovative sustainability technology. Furthermore, we develop a strategy framework for collective system building. To underpin our theoretical analysis empirically, we have conducted a case study in the Dutch smart grid field. The resulting strategy framework consists of four key areas: technology development and optimization, market creation, socio-cultural changes and coordination. Each of these key strategic areas is composed of a set of system-building activities.
\end{abstract}

(c) 2015 Elsevier Ltd. All rights reserved.

\section{Introduction}

Society-wide replacement of polluting technologies with alternative sustainability technologies enables consumers to maintain satisfying lifestyles without destroying the planet's ecological capacity for future generations. Therefore, sustainability technologies play an important role in sustainable development (Hargadon, 2010; Jansen, 2003; Nill and Kemp, 2009). Sustainability technologies are technologies which enable more efficient use of resources, less stress on the environment and even cleaning of the environment (Foxon and Pearson, 2008; Weaver et al., 2000). Many new technologies to solve or mitigate sustainability challenges have already been invented. However, their market implementation often fails - even if their performance is superior to incumbent technologies (Caniëls and Romijn, 2008). Actors who come up with radically new sustainability technologies find it difficult to further

\footnotetext{
* Corresponding author. HU University of Applied Sciences Utrecht, Daltonlaan 400, 3584 BK Utrecht, The Netherlands. Tel.: +31 638762320.

E-mail addresses: julia.planko@hu.nl (J. Planko), J.M.Cramer@uu.nl (J.M. Cramer), M.M.H.Chappin@uu.nl (M.M.H. Chappin), M.P.Hekkert@uu.nl (M.P. Hekkert).
}

develop their solution and to launch it on the market, because competing established technologies are widely supported by the socio-technological regime within which they have evolved (Geels, 2002; Kemp et al., 1998). Moreover, the adoption of a new sustainability technology sometimes requires inconvenient changes in consumption patterns, without offering additional functionalities to the consumer (Hargadon, 2010; Jansen, 2003). To overcome these obstacles and to enable a wide diffusion of sustainability technologies, significant socio-cultural, economic and legislative changes are required (Kemp and Loorbach, 2003). The active engagement of a wide range of public and private actors is necessary to achieve these changes (Farla et al., 2012; Van den Bergh et al., 2011). Among these actors, the driving forces of the transition process are often entrepreneurs and entrepreneurial managers $^{1}$ who develop and diffuse sustainability innovations (Hall et al., 2010; Teece, 2010). To increase the chances of success of

\footnotetext{
1 The narrow definition of the term entrepreneur describes new entrants who have a vision on new business opportunities in new markets (start-ups); the broader definition includes 'entrepreneurial managers', which are employees of incumbent companies who diversify their business strategy to take advantage of new developments (Hekkert et al., 2007).
} 
their technological innovation, they can - in collective efforts - try to achieve changes in the macro environment that support the implementation and user acceptance of their technology (Van de Ven, 1993).

Strategic management literature describes the need of innovative actors to collaborate strategically in order to shape their environment. Several authors suggest that firms collaborate in networks or industry clusters in order to compete with alternative technologies. Besides investing in their own development, they need to invest in the development of the business ecosystem in which they operate (Astley, 1984; Iansiti and Levien, 2004; Moore, 1996; Pitelis, 2012; Van de Ven, 1993). If they work together, they can create a favourable environment in which their firm can prosper. However, the strategic management literature does not provide insights into how to strategically build up such a supportive external environment. We attempt to fill this gap with complementary insights from the technological innovation systems literature.

The technological innovation systems (TIS) literature is part of the broader field of transition literature. Whereas the strategic management literature adopts the perspective of the firm, the transition literature analyses socio-technological change from the system perspective. The transition literature has generated various conceptual frameworks to analyse and stimulate the dynamics of socio-technological transition processes ${ }^{2}$, one of which is the technological innovation systems framework (Geels et al., 2008; Hekkert and Negro, 2009; Hekkert et al., 2007; Jacobsson and Bergek, 2011, 2006; Markard and Truffer, 2008a; Suurs et al., 2009). This framework has generated valuable insights into the processes and activities that innovative actors need to undergo and undertake in order to create a favourable environment in which their technology can flourish. This activity has been coined 'system building' (Musiolik et al., 2012). However, the insights from the system-building literature originate mainly from the system perspective and so far specific insights from the firm perspective have been missing. By complementing the TIS literature with insights from the strategic management literature, we have shifted the focus to the firm perspective. We will introduce the term 'collective system building' to describe processes and activities that firms can conduct in networks to collectively create a favourable environment for their innovative sustainability technology.

The objective of this paper is to combine insights from the strategic management literature and the technological innovation systems literature in order to provide a strategy framework for entrepreneurs and entrepreneurial managers to collectively build up a favourable environment for their sustainability technology. Networks of entrepreneurs and entrepreneurial managers who engage in strategic collective system building can use this practical framework to generate system-building strategies. The combination of these two literature strands will result in a strategy framework that considers both the system level and the firm level. Since we have analysed activities at the firm level that influence the system level, our framework for strategic collective system building contributes to both fields of literature. The strategic management literature so far does not provide insights into how to strategically build up a supportive external environment. Our framework will do so. The TIS literature so far focuses on the system-level, whereas we will add the firm perspective.

\footnotetext{
2 Socio-technological transitions are major changes in technological, organizational and institutional terms in both the production and consumption side, triggered by the innovation of a radically new technology. The implementation of the new technology in society entails the introduction of new services, business models and organizations (Farla et al., 2012).
}

To design a practical strategy framework for system-building entrepreneurs and entrepreneurial managers, we focused on two research questions. First, which system-building activities can entrepreneurs and entrepreneurial managers engage in to create a favourable environment for their technological innovation? Second, how can these activities be assembled into a practical strategy framework that can be used for strategic collective system building? To answer these research questions, we reviewed the literature on technological innovation systems with regard to system building and complemented it with insights from the strategic management literature. Moreover, we conducted a case study in the Dutch smart grid field to empirically underpin the theoretical analysis.

\section{Theoretical background on collective system building}

In this part we review the literature on system building. The concept 'system building' originated in the TIS literature. We start by giving an overview of system building as described in the TIS literature. Then we describe similar (but differently termed) concepts, originating in the strategic management literature, of collective actions that firms undertake to create a favourable environment. We conclude this part by combining these literature strands, by introducing the concept of collective system building and by providing an overview of collective system-building activities that we have identified in the literature.

\subsection{System building described in the technological innovation systems literature}

The term 'system building' originates from the TIS literature. System building is defined as "the deliberate creation or modification of broader institutional or organizational structures in a technological innovation system carried out by innovative actors. It includes the creation or reconfiguration of value chains as well as the creation of a supportive environment for an emerging technology in a more general way." (Musiolik et al., 2012, p. 1035) System building can be driven by a single, powerful actor (Hughes, 1987), but more often it is carried out as a collective effort by a network of actors ${ }^{3}$ (Garud and Kumaraswamy, 1995, 1993; Garud et al., 2007). In the course of this paper we will focus on collective efforts of system building by networks of actors, which we call 'collective system building'.

The TIS literature has generated valuable insights into the processes of system building (Markard and Truffer, 2008a; Musiolik et al., 2012). A technological innovation system contains all the components that influence the innovation process of a newly emerging technology. The TIS field is concerned with the key processes in an emerging technological innovation system (Bergek et al., 2008a). 'Functions' are dynamic key processes that take place in the emerging innovation system, triggered by activities by system actors (Bergek et al., 2008a; Hekkert et al., 2007). An overview of these functions is given in Table 1. Each key process contributes to building a favourable business ecosystem around the new sustainability technology. Moreover, the interactions between system processes accelerate the emergence and growth of an innovation system in virtuous circles and thus increase the chances of market success (Bergek et al., 2008b; Hekkert and Negro, 2009; Jacobsson and Bergek, 2011; Musiolik and Markard, 2011).

\footnotetext{
3 Such networks of actors consist of innovative actors, which are mainly entrepreneurs and entrepreneurial managers, but can also comprise policymakers or employees of public research institutes.
} 
Table 1

Key processes for building up a technological innovation system.

\begin{tabular}{|c|c|}
\hline TIS framework key process & Description of activities \\
\hline F1: Entrepreneurial experimentation & Testing new technologies, applications and markets, social learning processes \\
\hline F2: Knowledge development & Learning activities such as research and development and learning in a practical context \\
\hline F3: Knowledge diffusion & $\begin{array}{l}\text { Stimulating knowledge exchange through conferences, workshops and alliances between companies but also between } \\
\text { government, companies and the market }\end{array}$ \\
\hline F4: Guidance of the search & All the activities and events that convince actors to enter the TIS or to further invest in it \\
\hline F5: Market formation & $\begin{array}{l}\text { Creation of temporarily protected niche markets through favourable tax regimes, minimal consumption quotas, } \\
\text { environmental standards or creation of demand, e.g. through government procurement policies }\end{array}$ \\
\hline F6: Resource mobilization & $\begin{array}{l}\text { Financial and human resources need to be mobilized to enable the building-up of the innovation system (monetary or } \\
\text { in-kind) }\end{array}$ \\
\hline F7: Creation of legitimacy & $\begin{array}{l}\text { Counteract resistance to change; lobbying to create legitimacy of the new technology, to put the technology on the } \\
\text { political agenda, and for favourable tax regimes }\end{array}$ \\
\hline
\end{tabular}

Based on Bergek et al., 2008b; Hekkert and Negro, 2009; Hekkert et al., 2007; Jacobsson and Bergek, 2011; Suurs and Hekkert, 2009 ; Suurs et al., 2009.

Several versions of the TIS framework can be found in the TIS literature. Depending on the author, the TIS framework has 7-9 functions. The core processes described are displayed in the table above.

Recently, Musiolik and Markard stated that the coordination of actors and activities along the value chain is a key process that enhances the overall functioning of the innovation system, but which 'has not been mapped yet' (Musiolik and Markard, 2011). For a well-functioning innovation system, the emergence and coordination of specialized goods and service providers is important (Bergek et al., 2008b; Foxon et al., 2004). The creation of standards such as technical guidelines and standard components is important for coordination (Musiolik et al., 2012; Van de Ven, 1993). For strategic collective system building, the coordination of activities is of major importance. Moreover, socio-cultural changes need to be triggered for the new technology to become widely accepted. Users need to be willing to change their behaviour patterns so that they can adopt the new technology (Geels, 2004). Changes in the education system are necessary to change values and norms in society and to provide sufficiently skilled workforce (Kemp and Soete, 1992). Therefore, we have incorporated 'coordination along the value chain' and 'triggering socio-cultural changes' into the development of a strategy framework for system building.

The TIS framework provides a comprehensive overview of system level processes. It has been developed and tested for use by policymakers who intend to support the development and diffusion of an emerging sustainability technology by stimulating key processes at the system level. However, the TIS framework can also be used by networks of entrepreneurs who want to collectively create a supportive environment around their new technological sustainability innovation. Since the TIS key processes take place at the system level, but firms operate on the micro level, the TIS processes have to be broken down into strategic activities which can be carried out by firms. To introduce the firm perspective, we have complemented the TIS literature with insights from the strategic management literature.

\subsection{System building described in the strategic management literature}

The terms 'system building' and 'collective system building' have not yet been mentioned in the strategic management literature. Most strategic management literature focuses on firm-centred activities. However, several literature strands within the strategic management literature describe collective efforts by actors to influence the environment in which they develop an innovation.

Van de Ven's theory of an 'entrepreneurial infrastructure' defines how entrepreneurs who want to implement an innovative technology need to build an entrepreneurial infrastructure together with other businesses in their industry sector (Van de Ven, 1993). Entrepreneurs have to develop their own innovation and design their individual business strategy, but at the same time they need to collaborate strategically with actors along the supply chain, including direct competitors, to build a supportive infrastructure which will stimulate the fast diffusion of their technology. Elements of this entrepreneurial infrastructure are market consumption, institutional arrangements, resource endowments and proprietary activities $^{4}$ (Van de Ven, 1993). Collaborating ("running in packs") with competitors will increase the likelihood that their technology will be successful (Van de Ven, 2005, 1993). Individual entrepreneurs need to understand that individually they do not have the resources, power or legitimacy to produce change. They need to become "nodes in value chain networks" and compete as a network with other networks (Van de Ven, 2005). Building a supportive system around their new technology and collectively striving for change towards a new technological regime are essential elements of collective system building.

In the strategic management literature, the term 'business ecosystem' is used to describe the economic and social landscape of which an individual business is part and in which it evolves together with other businesses (Iansiti and Levien, 2004; Moore, 1996). A business ecosystem is a business network that goes beyond the supply chain of the focal company. It consists of all the individuals with whom a business interacts, including suppliers, technology producers, customers, competitors, producers of complementary assets, sellers, financial actors, governmental actors, media and regulatory agencies. It is impossible to draw precise boundaries of a business ecosystem (Iansiti and Levien, 2004; Moore, 1996). The analogy with a biological ecosystem is used to highlight the interrelatedness and interdependency of businesses in a changing environment. The health of the ecosystem determines the success and survival of the individual firm (Iansiti and Levien, 2004). The key to a successful ecosystem is a network of mutually beneficial relationships with other ecosystem actors. Organizations need to intelligently co-evolve with their overarching business and social environment. Especially with regard to innovation, a strong collaboration with customers and supplier partners is essential, as well as the good management of a wide network of co-evolving organizations (Moore, 1996). Iansiti and Levien (2004) predict that for technology-innovating firms, competition will occur between business ecosystems or business ecosystem

\footnotetext{
4 These four terms constitute the pillars of Van de Ven's concept of entrepreneurial infrastructure. In brief: market consumption includes the changing of norms as well as market creation; institutional arrangements refer to laws, regulation and legitimation; resource endowments are science, technology, financing and competence training; proprietary activities include product development, business functions and resource channels (Van de Ven, 1993).
} 
domains, rather than between individual firms. Business strategies need to go beyond the firm's individual strategy, and need to consider the network environment in which the company operates (Iansiti and Levien, 2004).

Pitelis describes that some entrepreneurial managers collaborate in networks or clusters and engage in inter-firm collaboration to co-create markets of ecosystems, aimed at capturing value from resulting business opportunities. They collaborate when they perceive a potential for value capture that is higher than from stand-alone activities (Pitelis, 2012). The description of their cocreation of a supportive ecosystem matches the concept of collective system building.

Astley also assumes a systemic viewpoint. He uses a 'social ecology' approach and argues that businesses should not regard the environment in which they operate as an intractable externality to which they are exposed and to which they merely react. In contrast, they should realize that they are component parts of their environment, and through interaction with each other create resources and institutions that generate opportunities and threats for organizations. In order to pro-actively manage organization-environment relationships, Astley advises businesses to generate a strategy at the collective level (in addition to their individual business strategy). He defines collective strategy as "the joint formulation of policy and implementation of action by the members of interorganizational collectivities" (Astley, 1984, p. 527). Collective strategies guide inter-firm networks to the collective mobilization of resources and actions oriented towards the achievement of a common goal (Astley and Fombrun, 1983; Astley, 1984). Astley describes two important elements of collective system building. First of all, companies do not merely react to changes in their environment, but they can actively shape it. Second, companies need to formulate strategies at the network level in order to shape their environment.

Following the same line of thought, Davenport et al. (2007) argue that today's fast-paced innovation economy requires a new strategic management mind-set, approach and toolbox. Companies need to abandon the idea of individual competition and instead understand that they need to compete in clusters against other clusters. They need to adopt a holistic view of the business ecosystem in which they operate and develop their knowledge and capabilities together with peer businesses. Instead of individual growth, they need to focus on holistic value creation through collaboration in business networks (Davenport et al., 2007). The holistic view of value creation as a business ecosystem is an important element of collective system building.

To summarize, the strategic management literature states that to develop and implement innovative technologies, entrepreneurs need to strategically cooperate in business ecosystems, in which they co-evolve and co-create value. Moreover, they need to change the environment in which they want to implement their innovation. The first two columns of Table 2 give an overview of the respective literature strands.

\subsection{Strategic collective system building}

The review above shows that both the technological innovation systems framework and the strategic management literature highlight the importance of collaboration and the need to build up a favourable environment around the new technology. However, concrete system-building activities are hardly mentioned in the strategic management literature. Column 3 of Table 2 shows the overlap of the respective strategic management literature strand with TIS literature, and column 4 summarizes how the TIS literature can complement it. Although the TIS literature does mention system-building activities, it is focused on the system perspective and system level changes, and the firm perspective is underrepresented. Combining both literature fields therefore generates valuable insights into strategic collective system building for entrepreneurs and entrepreneurial managers who want to achieve system level changes, by carrying out strategic activities at the firm level. In other words, the TIS literature and the strategic management literature complement each other. The strategic management literature takes on a firm perspective which considers the environment ('inside out thinking'), whereas the TIS literature takes on a system perspective in which it considers the firm ('outside in thinking'). Based on the literature discussed above, we introduce the term 'collective system building'. The term 'collective system building' emphasizes the collective nature of system building, as opposed to 'system building' which can also be driven by very powerful individual actors. Collective system building can be carried out intuitively or strategically. We define 'strategic collective system building' as the strategic activity of networks of entrepreneurs and entrepreneurial managers to build up a supportive environment and infrastructure for their innovative sustainability technology. The concept 'strategic collective system building' has been derived from literature. According to the literature reviewed above, firms do not have to wait for a supportive environment to emerge, in which their innovation will flourish. They can pro-actively create such an environment. Successful strategic collective system building is expected to lead to a wider adoption of the technology, larger markets and greater implementation in society. An overview is provided below of the different collective system-building activities that have been identified in the literature.

\subsection{Strategic collective system-building activities}

This section provides an overview of collective system-building activities: activities that actors can strategically engage in, so as to build a supportive environment in which they can commercialize their innovative technology. Based on these activities, we have developed a strategy framework for collective system building.

We use the system-building activities mentioned in the TIS literature as the starting point, and complement them with insights from the strategic management literature. Collective system-building activities which are described in the TIS framework are: testing new technologies, applications and markets; knowledge development; knowledge exchange (Bergek et al., 2008b); co-creation of products and service (Musiolik et al., 2012); creation of temporarily protected niche markets (Bergek et al., 2008a); creating a shared vision (Negro et al., 2008); and standardization (Bergek et al., 2008b). The review of the TIS literature also revealed some other collective system-building activities that are mentioned but not explicitly described in the TIS framework. They are described in the broader literature on sustainable technological change. These collective system-building activities are: collaborating with government to adapt legislation (Kemp and Loorbach, 2003; Kemp and Soete, 1992), changing user behaviour (Geels, 2004), changing the education system (Kemp and Soete, 1992), and generating a skilled pool of labour (Wolfe and Gertler, 2004).

Moreover, we brought in the firm perspective by reviewing the strategic management literature. The strategic management literature describes elements of system building (as shown in Table 2), but it does not provide a list of activities for building up a supportive innovation system. Nevertheless, some activities that contribute to the creation of a supportive system around a new technology could be derived from this literature strand: collaborative marketing to raise user awareness (Hagedoorn and Schakenraad, 1994; Rothwell, 1991; Van de Ven, 2005; Van de 
Table 2

Arguments for system building in the strategic management literature.

\begin{tabular}{|c|c|c|c|}
\hline \multirow{2}{*}{$\begin{array}{l}\text { Literature strand \& } \\
\text { authors }\end{array}$} & \multirow[t]{2}{*}{ Argument/concept } & \multicolumn{2}{|l|}{ Relation to TIS literature } \\
\hline & & In line with TIS literature & $\begin{array}{l}\text { Missing in strategic management } \\
\text { literature }\end{array}$ \\
\hline $\begin{array}{l}\text { Entrepreneurial } \\
\quad \text { infrastructure } \\
\quad \text { (Van de Ven, 1993, 2005) }\end{array}$ & $\begin{array}{l}\text { Entrepreneurs need to collaborate } \\
\text { strategically with other businesses of } \\
\text { their industry to build a supportive } \\
\text { infrastructure around their technology }\end{array}$ & $\begin{array}{l}\text { - Building a supportive system around } \\
\text { their technology } \\
\text { - Competition as a network against } \\
\text { other networks (competing } \\
\text { technologies) }\end{array}$ & $\begin{array}{l}\text { - The dynamic processes necessary to } \\
\text { build the system } \\
\text { - The inertia from the existing } \\
\text { (competing) technological regime }\end{array}$ \\
\hline $\begin{array}{l}\text { Business ecosystem } \\
\quad \text { (Iansiti and Levien, 2004; } \\
\text { Moore, 1996; Pitelis, 2012) }\end{array}$ & $\begin{array}{l}\text { An individual business is merely a part } \\
\text { of the business ecosystem it operates } \\
\text { in; the health of the business ecosystem } \\
\text { determines the success of the individual } \\
\text { firm }\end{array}$ & $\begin{array}{l}\text { - Interrelatedness and interdependency } \\
\text { of business in a fast-changing } \\
\text { environment } \\
\text { - Co-evolution of firms } \\
\text { - Co-creation of markets } \\
\text { - Competition between } \\
\text { (technological) systems } \\
\text { - Business strategies for the network } \\
\text { level necessary }\end{array}$ & $\begin{array}{l}\text { Strategies on how to establish a } \\
\text { flourishing business ecosystem, and on } \\
\text { how to proactively change the } \\
\text { environment }\end{array}$ \\
\hline $\begin{array}{l}\text { Social ecology approach } \\
\text { (Astley, 1984; } \\
\text { Astley and Fombrun, 1983) }\end{array}$ & $\begin{array}{l}\text { Firms are not merely exposed to their } \\
\text { environments, but they are component } \\
\text { parts of it; through interaction they can } \\
\text { create resources and institutions }\end{array}$ & $\begin{array}{l}\text { - Formulation of collective strategy } \\
\text { (strategy as a network of firms) } \\
\text { - Firms can actively change or shape } \\
\text { the environment in which they } \\
\text { operate }\end{array}$ & $\begin{array}{l}\text { Strategies on how to influence the } \\
\text { environment and on how to create } \\
\text { resources and institutions }\end{array}$ \\
\hline $\begin{array}{l}\text { Cluster competition } \\
\text { (Davenport et al., 2007) }\end{array}$ & $\begin{array}{l}\text { Firms co-create value through } \\
\text { collaboration in business networks; } \\
\text { firms compete as clusters against other } \\
\text { clusters (instead of individual } \\
\text { competition) }\end{array}$ & $\begin{array}{l}\text { - Collaboration in networks to create } \\
\text { value } \\
\text { - Competition in networks against } \\
\text { other networks (of competing } \\
\text { technologies) }\end{array}$ & $\begin{array}{l}\text { View on the external environment } \\
\text { which can be created by competing } \\
\text { networks }\end{array}$ \\
\hline
\end{tabular}

Ven et al., 2008b), collaborative competition against other technology clusters (Bengtsson and Kock, 2000; Cooke, 2008; Davenport et al., 2007; Porter, 1998; Ritala and Sainio, 2014), establishing collaboration-prone organizational cultures (Lam, 2004; Ritter and Gemünden, 2003), defining a common goal (Harmaakorpi, 2006a; Lambooy, 2004), and providing a platform for open innovation (Chesbrough and Appleyard, 2007; Laszlo, 2003).

\section{Method}

In the previous part, we derived from the literature the concept of strategic collective system building. In addition, several activities that were potentially relevant for system building were identified in the literature reviewed. The next step was to develop a strategy framework for collective system building; in other words, we wanted to indicate the activities that system-building firms can strategically undertake to build a supportive technological innovation system in which their innovation can flourish and can be commercialized. In order to fully explore all the activities that are ongoing in the field and to find empirical evidence on collective system building and system-building activities, we conducted a single embedded case study in the field of the Dutch smart grid sector.

\subsection{Selection of case study}

The Dutch smart grid sector has been chosen because it is an emerging technological system. A smart grid is an electricity network combined with an ICT network, which is adapted to the introduction of renewable energy sources (Interreg IVB, 2011). Smart grids are essentially not one technology, but a complex set of intertwined technologies. For example, smart devices, such as a smart washing machine, can be automatically switched on when solar panels produce a lot of electricity, thanks to specially designed software; this can prevent the grid from being supplied with too much energy. Due to the complexity and interdependency of this new technology, actors know that they need to collaborate. This makes the smart grid sector a relevant case in the context of collective system building. In the Netherlands, small start-ups all along the value chain as well as incumbent energy companies that try to diversify their business are working hard to develop and implement smart grid technology. Actors are prone to collaborate and they form various networks with different constellations of actors. These networks have set up pilot projects, for example to test full-scale smart grid concepts in practice or to work on the standardization or the acceleration of smart grid development and implementation (Kema, 2012; Laan, 2012; NL Agency, 2012a, 2012b; SEC, 2012). Moreover, the Dutch government supports the development of this field and launches projects and programmes which aim to accelerate the collaboration of companies that are active in the smart grid field. In addition, there are numerous other national and international networks, pilot projects and collaborative projects, with different constellations of public and private actors (Hertzog, 2013; Hübner and Prüggler, 2011). These factors make the Dutch smart grid field a suitable case for analysing the processes of collective system building.

\subsection{Data collection}

To collect data, semi-structured in-depth interviews were carried out with 14 key actors in the field. First, a list of 25 key actors was compiled, based both on information provided by a key player in the Dutch smart grid field and on the report "Who is who guide players in the Dutch smart-grid sector', published by NL Agency, an executive agency of the Dutch government (NL Agency, 2012c). From this list of 25 potential interviewees, ten people were selected that broadly covered the field. They were either owners of start-ups or high-ranked managers from major companies along the smart grid value chain. Based on the information gained during these interviews, four additional interview partners were asked to 
participate. These four had been mentioned by the interviewees as important players in the field.

Of the fourteen key actors interviewed, twelve can be classified as entrepreneurs in the broad definition of the term, or intrapreneurs (managers in large companies who try to seize new business opportunities by diversifying), and two as entrepreneurs in the narrow sense (start-ups). The intrapreneurs were highranked managers instructed by their firms to develop business opportunities in the smart grid field. They held positions such as senior director, executive partner, business developer, smart grid division manager or senior project development manager.

The face-to-face interviews consisted of two parts. In the first part, the respondents were asked to reflect upon the general question of what is necessary to make the technology a success. They were also asked to discuss activities necessary for system building. In the second part, the respondents were shown the TIS key functions and the list of activities based on the literature review (see Section 2.4). Subsequently, they were asked to reflect upon these activities in terms of their actual usage, the respondents' involvement in conducting these activities, and the relevance of the activities in the context of system building. The interviews took 80-140 minutes and were conducted between December 2012 and March 2013.

\subsection{Data analysis}

All interviews were transcribed and analysed using Atlas.ti software. This analysis consisted of two main steps. The first step resulted in a set of system-building activities, and in the second step these activities were clustered. First, we coded the data according to the activities derived from the literature review. However, if it appeared to be impossible to refer back to the literature reviewed, we used wider strategic management literature to base the new codes on. The outcome was a set of 22 system-building activities, which entrepreneurs of the Dutch smart grid field perceive as important for strategic collective system building.

The next step was to analyse the relationships between these activities and entrepreneurs' motivations to engage in these activities, i.e. their ultimate system-building goal when engaging in these activities. This enabled us to cluster the activities into overarching categories, based on the system-building goal they contribute to. To refine our clusters, we compared the resulting system-building objectives with the literature on system building. In an iterative process, we compared the findings from the interviews with the existing literature on system building. This analysis revealed four main clusters to which system-building activities can be assigned. For example, entrepreneurs mentioned that they engage in knowledge development, diffusion and testing activities in order to optimize their technology. When these findings were compared with the literature, it was concluded that one important objective of system building is the development and optimization of technology. This is how the first cluster Technology development and optimization emerged. Applying this approach, we identified four clusters: Technology development and optimization, Market creation, Socio-cultural changes and Coordination.

\subsection{Validation of results}

After finishing our analysis, we validated our results in several steps. First, we constructed an online survey in which we asked whether the respondents agreed with our analysis on the systembuilding activities that were revealed as being necessary and important. Respondents could answer on a 5-point Likert-scale, from 'very unimportant for system building' to 'very important for system building'. In addition, they could choose 'not necessary for system building' and give comments on each cluster of activities, in case they thought an activity was missing or if they disagreed with a specific category. We also checked that they agreed with the over-arching system-building goals.

We used the survey to collect data from two different groups. The first group consisted of eight of our interview partners. With this step we wanted to make sure that we had correctly perceived and displayed the opinions of the interviewees in the developed framework.

The second group comprised of different managers of the Dutch smart grids sector, who had not been interviewed by us previously. During a practitioners conference on smart grids, fourteen managers were approached to participate in the research. They were asked to fill in the same questionnaire as the group described above. This helped us to also validate the results for the smart grids sector. In the end, half of them, seven entrepreneurs, filled in the survey.

The second step of the validation was a 1.5-hour meeting in a workshop setting, attended by approximately twenty entrepreneurs from different fields. The aim of the workshop was to discuss the framework and its applicability to other industries.

\section{Findings}

First, we examine whether the concept of strategic collective system building, which we introduced based on our literature review, actually occurs in practice. Subsequently, it is determined whether practitioners engage in the system-building activities derived from the literature and which additional system-building activities were mentioned. Moreover, we consider how the system-building activities can be reframed so that practitioners can use them more easily for strategy making in the future.

\subsection{Strategic collective system building in practice}

Our data revealed that entrepreneurs and entrepreneurial managers of the Dutch smart grid system were aware that they need to collaborate to implement their technology in the market. They realized that such implementation requires a transition towards an efficient decentralized renewable energy system, which can only be achieved in collective efforts. As one interviewee stated, "A single company cannot change the system; companies have to do it jointly." [P6] Close collaboration along the value chain is necessary to build a new technological system: "We have to work together with other companies, mainly with clients, with user groups - everyone. Together, together, together. It is the core of our mission, which is building the system." [P10] Interviewees were aware that they need to work together with all kinds of actors along the whole value chain: customers, competitors, suppliers, universities and the government. As one interviewee said, "We ideally want to collaborate with all of them, all kind of actors. Normally as a company your main actor is a customer, somebody who buys your equipment, but we also want to have our contacts with the government; we also want to have our contacts with the universities." [P14] Furthermore, the interview partners were aware that they were part of a technological system, and that collaboration was required to co-develop products and services which are compatible and will enable the system to function efficiently: "There is not a company in the world that can develop all the components, the system architecture [...], so you have to bring all these companies together or at least a great number of companies; we are not enough yet. In that way, you can design the system and while you are doing that, these companies are developing services and products and solutions that fit in that system." [P2]. 
Entrepreneurs and entrepreneurial managers reasoned that the advantage of collaborating with competitors is that standards can be set which help the new technology to be spread and compatible systems to emerge. ${ }^{5}$ Moreover, the interviewees were aware that cooperation on optimizing the technology or its inputs will lead to a greater adoption of the technology. They know that if they want to reap business opportunities in this new system, they need to cooperate. However, they admitted that it is not easy to collaborate at such a large scale and with so many different actors.

We found that entrepreneurs and entrepreneurial managers do engage in system-building activities. They are aware that they have to solve problems and overcome barriers at the system level. However, they do not strategically plan system level changes. Instead, they formulate their strategies at the firm level, and collaborate in networks to achieve their companies' objectives. As a result, they intuitively engage in system-building activities which tackle problems at the system level. However, most interviewees stated that a more strategic approach to collective system building would lead to faster diffusion and adoption of their new technology. To summarize, entrepreneurs and entrepreneurial managers are aware that they have to build a system, and they consider system-level changes; yet, in most cases, their strategic focus is on the firm level.

\subsection{System-building activities mentioned by entrepreneurs and entrepreneurial managers}

This section focuses on the system-building activities that were discussed during the interviews and the underlying goals entrepreneurs aimed to achieve by carrying out these activities. Our research revealed 22 system-building activities. Table 3 gives an overview of these activities. The seven functions of the technological innovation systems framework needed to be broken down into system-building activities that entrepreneurs can strategically engage in. Entrepreneurs agreed that these activities are important for system building (column 3). They further agreed that the system-building activities derived from the strategic management literature are important for system building (column 4). A few system-building activities were considered important by interviewees, but this could not be underpinned by the TIS literature or the strategic management literature reviewed in Section 2 (column 5).

The purpose of a strategy framework is to help managers and other decision makers to structure and organize information on which they can base their strategic decisions (Knott, 2006; Mintzberg et al., 1998). In order to draw up a practical strategy framework that can be used by entrepreneurs and entrepreneurial managers for strategy making, we needed to cluster the systembuilding activities. By clustering the activities into categories, a structure for organizing information is introduced to the framework. The category Technology development and optimization summarizes all the activities that lead to the development and optimization of the new technology, including supplementary products and services. These activities are usually seen as core activities by actors who want to launch an innovative technology. The second category is Market creation. Many authors, especially management scholars, highlight the importance of market creation

\footnotetext{
${ }^{5}$ Some interviewees stated that collaboration within a nascent industry is not a new phenomenon. Examples were given of optical discs and mobile telephony: "DVDs would never have been a success if there had been only one company. It was the fact that many companies were involved and that it was really the industry that put it there that caused it to become one of the best solutions in the world. The same is true for mobile telephony: if there had not been a GSM standard, they couldn't have sold mobile phones." [P5].
}

by push and pull factors. If users are not aware of or interested in the existence of an innovative technology, this technology will not succeed in the market, however optimized it may be (Foxon and Pearson, 2008; Hall and Khan, 2003; Hargadon, 2010). The third category is Stimulation of socio-cultural changes. Socio-cultural changes such as changes in the mind-sets of customers, producers and policymakers are often a necessary requirement for a new sustainability technology to be embraced by society. Furthermore, changes in the education system need to take place. These three categories also represent the goals of system building. In addition, a range of activities were mentioned which entrepreneurs carry out in order to coordinate system-building activities and thus accelerate the process of system building. We clustered these activities into the category Coordination. This category is not a system-building goal in itself, but it facilitates and accelerates system building and is therefore another key area for strategic system building. It comprises all the activities and processes that contribute to a better coordination of system-building activities. This category is visualized on a different level in Fig. 1 (at the centre of the triangle), as it is not a goal of system building, but a facilitator and accelerator of the system-building goals represented by the other three categories.

\section{Discussion of the strategy framework}

This part discusses the strategy framework and the individual system-building activities it is composed of. We start by describing and discussing a cluster as visualized in Fig. 1, and then we elaborate on each of the system-building activities that make up the cluster. In each section, we first discuss the system-building activities derived from the TIS literature and confirmed by our empirical data, followed by the system-building activities that can be underpinned by the strategic management literature as summarized in Section 2.4. Subsequently, we describe additional systembuilding activities that emerged from our case study data, but that could be linked neither to the TIS literature, nor to the strategic management literature reviewed in the theory section above.

\subsection{Technology development and optimization}

A well-functioning and viable technology is the key component of a new innovation system. If the technology is faulty, all other system-building activities may be in vain. Especially in the view of system-building entrepreneurs, who often happen to be engineers, the development and optimization of the new technology can be expected to be the primary goal. Below we briefly describe activities that contribute to the development and optimization of the innovative technology.

The three system-building activities (1) testing new technologies, applications and markets, (2) knowledge development and (3) knowledge exchange were derived from the TIS framework (Bergek et al., 2008c; Hekkert et al., 2007; Jacobsson and Bergek, 2011). Entrepreneurs found these activities or processes vitally important. However, they remarked that from their perspective, the three activities often overlapped and were perceived as one activity. For example, a shared pilot project simultaneously contributes to testing, knowledge development and knowledge exchange. With regard to strategy design, this finding highlights the importance of clustering the system-building activities according to systembuilding goals. Co-creation of products and services was mentioned in the TIS framework as well as in the strategic management literature, specifically the business ecosystem literature. Collective development efforts stimulate complementarity of products and services as well as cost-effectiveness; thus, the system as a whole is strengthened (Hekkert et al., 2007; Iansiti and Levien, 2004; Moore, 
Table 3

System-building activities and the literature fields they can be related to.

\begin{tabular}{|c|c|c|c|c|}
\hline Cluster & System-building activity & $\begin{array}{l}\text { Stated by entrepreneurs and } \\
\text { in line with TIS literature }\end{array}$ & $\begin{array}{l}\text { Stated by entrepreneurs and } \\
\text { in line with strategic } \\
\text { management literature }\end{array}$ & $\begin{array}{l}\text { Stated by entrepreneurs; } \\
\text { not mentioned in the } \\
\text { literature reviewed in Section } 2\end{array}$ \\
\hline \multirow{6}{*}{$\begin{array}{l}\text { Technology } \\
\text { development \& } \\
\text { optimization }\end{array}$} & $\begin{array}{l}\text { Testing new technologies, applications } \\
\text { and markets }\end{array}$ & $\mathrm{x}^{\mathrm{a}}$ & $\mathrm{o}^{\mathrm{b}}$ & \\
\hline & Knowledge development & $\mathrm{x}$ & 0 & \\
\hline & Knowledge exchange & $\mathrm{x}$ & 0 & \\
\hline & Co-creation of products and services & $\mathrm{x}$ & o & \\
\hline & $\begin{array}{l}\text { Development of commercially viable } \\
\text { products }\end{array}$ & & & $\mathrm{x}$ \\
\hline & Feedback loops with user groups & & & $\mathrm{x}$ \\
\hline \multirow[t]{5}{*}{ Market creation } & $\begin{array}{l}\text { Creation of temporarily protected niche } \\
\text { market }\end{array}$ & $\mathrm{x}$ & & \\
\hline & $\begin{array}{l}\text { Collaboration with government to } \\
\text { adapt legislation }\end{array}$ & $\mathrm{x}$ & & \\
\hline & $\begin{array}{l}\text { Collaborative marketing to raise user } \\
\text { awareness }\end{array}$ & & $\mathrm{x}$ & \\
\hline & $\begin{array}{l}\text { Collaborative competition against other } \\
\text { technology clusters }\end{array}$ & & $\mathrm{x}$ & \\
\hline & Generate new business models & & & $\mathrm{x}$ \\
\hline \multirow[t]{5}{*}{ Socio-cultural changes } & Changing user behaviour & $\mathrm{x}$ & & \\
\hline & Changing the education system & $\mathrm{x}$ & & \\
\hline & Generating a pool of skilled labour & $\mathrm{x}$ & & \\
\hline & $\begin{array}{l}\text { Establishing collaboration-prone } \\
\text { organizational cultures }\end{array}$ & & $\mathrm{x}$ & \\
\hline & Creating new facilitating organizations & & & $\mathrm{x}$ \\
\hline \multirow[t]{7}{*}{ Coordination } & Standardization & $\mathrm{x}$ & & \\
\hline & Creating a shared vision & $\mathrm{x}$ & 0 & \\
\hline & Defining a common goal & & $\mathrm{x}$ & \\
\hline & $\begin{array}{l}\text { Providing a platform for open } \\
\text { innovation }\end{array}$ & & $\mathrm{x}$ & \\
\hline & System orchestration & & & $\mathrm{x}$ \\
\hline & $\begin{array}{l}\text { Thinking in system-building roles } \\
\text { instead of company objectives }\end{array}$ & & & $\mathrm{x}$ \\
\hline & $\begin{array}{l}\text { Creating transparency of all activities } \\
\text { going on in the field }\end{array}$ & & & $\mathrm{x}$ \\
\hline
\end{tabular}

a " $x$ " indicates that these activities mentioned by entrepreneurs are described in the respective literature field.

b "o" indicates that these activities are not only derived from the TIS framework and validated empirically, but are also mentioned in the strategic management literature.

2005; Pitelis, 2012; Ritala and Hurmelinna-Laukkanen, 2009). Development of commercially viable products emphasizes that while optimizing the functionality of the new technology, developers need to keep in mind the added value for the customer as well as the user-friendliness of their products and services. Feedback loops with user groups can be established as part of pilot projects or through communication platforms. In order to optimize technology, especially with regard to user-friendliness and user acceptance, the cooperation with user groups can provide valuable information. This information needs to be captured and processed

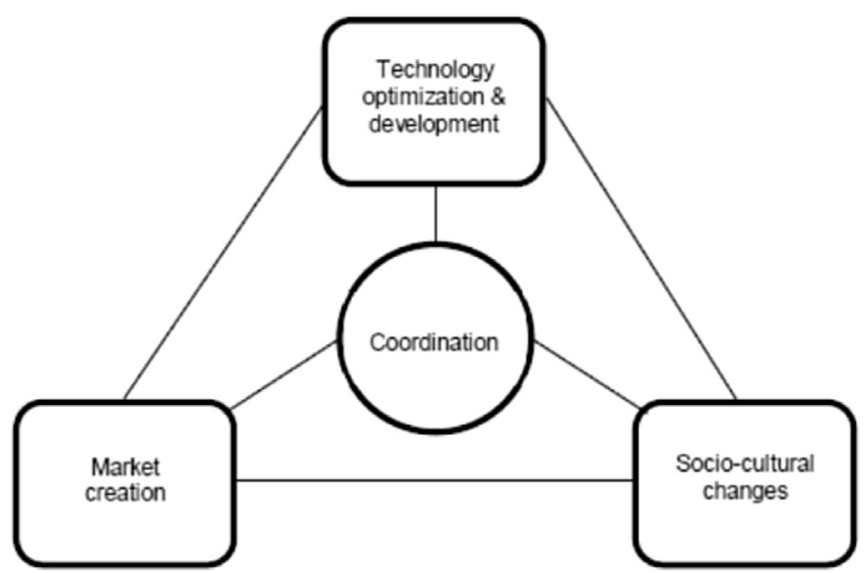

Fig. 1. Strategy framework for collective system building by entrepreneurs. and used for further development of the technology. These last two activities are derived from the case study data. Of course, the development of products is also part of the TIS literature (F1: entrepreneurial experimentation), to which the last two activities might be added. However, the specific distinction that the products should also be commercially viable (and not just an optimally functioning technology, which may be too expensive or difficult to use) is not explicit in the TIS framework. In addition, the creation of feedback loops with user groups is not specifically described in the TIS framework, because the TIS literature focuses on the system level (from a policymaker's perspective) and our research focuses on the entrepreneur's perspective. Taking on the firm perspective generates this more specific distinction of system-building activities.

\subsection{Market creation}

One of the main conditions for a new technology to be widely adopted is that there is a market for it (Hall and Khan, 2003; Rothwell, 1991; Van de Ven, 2005, 1993). Push and pull factors have to be considered for market creation (Foxon and Pearson, 2008), producers have to be supported and interest needs to be raised among potential customers. Especially for radically new technologies, an effort has to be made to raise user awareness and demand (Hargadon, 2010; Markard and Truffer, 2008b). Moreover, regulation needs to be adapted to enable and support the new technological system, and to allow market forces to come into play (Foxon and Pearson, 2008; Foxon et al., 2004; Hall and Khan, 2003; Loorbach and Rotmans, 2006). 
Several authors argue that the creation of temporary niche markets is an important measure for a new technological innovation to further develop into a technological regime (Geels, 2005, 2002; Markard and Truffer, 2008a). Regarding smart grids, however, several interviewees stated that more than the creation of niche markets, changes in the regulatory framework support the commercialization of the new technology. They indicated that temporary niche markets can keep in place the existing structures of the macro-environment which favour and reinforce the incumbent technological regime. However, these interviewees conceded that temporarily protected niche markets have proven successful for other innovative technologies. These findings show that not all system-building activities may be applicable for all technologies.

All entrepreneurs interviewed acknowledged the importance of collaboration with other system actors to raise user awareness and demand for the new technology. Potential customers have to be aware that there is a new technology and that it offers benefits. Consumers have a selective perception and only pick up specific messages about products if they have a basic knowledge about the product and its general functionalities (Kotler et al., 2008). Therefore, when marketing radical innovations, first a general awareness and understanding of the technology has to be generated. This first marketing phase can be conducted collaboratively by innovation system actors. This enables them to combine their resources and achieve higher leverage effects (Hagedoorn and Schakenraad, 1994; Rothwell, 1991; Van de Ven, 2005, 1993; Van de Ven et al., 2008a). Once potential customers are aware of the new technology, individual companies can start communicating specific facts about and benefits of their own particular product or service.

Entrepreneurs were aware that if they want to achieve largescale transitions, they need to collaborate in order to overcome the existing technological regime. Strategic management literature suggests that the actors of the new technological regime have to understand that they need to compete as a cluster (network of actors) with other clusters of alternative technologies (Cooke, 2008; Davenport et al., 2007; Porter, 1998; Wolfe and Gertler, 2004). If firms understand that they do not have to compete with peers that develop a similar technology, but rather compete collectively against alternative technologies, they can create a larger market for their product or service than if they competed individually (value creation). This larger market can then be divided up (value appropriation) by the collaborating companies (Bengtsson and Kock, 2000; Porter and Kramer, 2011; Ritala and HurmelinnaLaukkanen, 2009; Ritala and Sainio, 2014).

Most interview partners pointed out that the current legislation is one of the main obstacles to the introduction of the new technology. The national government plays a major role in creating a market for the new technology. It can adapt legislation in order to support the implementation of the new technology (Fischer, 2008; Georg, 1994; Kemp and Loorbach, 2003; Kemp and Soete, 1992; O'Connor, 1997). Entrepreneurs who want to commercialize a sustainability technology should inform the government of the new technology so that the government can design a supportive regulative framework (Suurs et al., 2009). Networks of entrepreneurs can lobby to convince governmental actors to put the support of the new technology on the political agenda (Hekkert et al., 2007).

The generation of new business models is necessary to allow the market forces to come into play and support the implementation of the new technology. Entrepreneurs stated that to make their technology commercially viable, the market should be designed in such a way that economic incentives are provided to those who have to make investments, change their user behaviour or switch over to the new technology. In order to design such stimulating business models which incentivize investments in the new technology and the change of user behaviour, the government would have to conduct regulative changes. The cooperation of private actors (who have the necessary knowledge) and public actors (who have regulative power) is necessary to draw up and enable feasible business models. For example, government regulations concerning the energy system were designed many years ago for the incumbent central fossil fuel-based energy system. These regulations do not permit specific pricing mechanisms (e.g. real time pricing) that would allow companies to reap financial benefits from applying smart grid technology or stimulate users to change their behaviour.

\subsection{Socio-cultural changes}

For technological sustainability innovations to be widely adopted, they need to be embedded in society. System-building entrepreneurs have to strive for changes in the mind-sets of consumers and producers; these entrepreneurs need to change values and norms in favour of the new technology. Individually, they do not have the means and the power to achieve socio-cultural changes ${ }^{6}$; however, they can trigger these changes in collective efforts and in collaboration with the government. Considering the lengthy time horizons of socio-cultural changes, it is advisable to start working on these changes very early in the system-building process. The entrepreneurs interviewed acknowledged that socio-cultural changes are exceedingly important if the technology is to be adopted, but that this area is still often neglected. Some interview partners mentioned that neglecting the necessary socio-cultural changes in the product development phase is one of the main obstacles to a successful implementation of a technology. These findings can be related to the strategic management literature as well as the TIS literature and the broader literature on sustainable technological change. Hall and Khan state that even the most optimally functioning new technology may commercially fail if it cannot be embedded in society (Hall and Khan, 2003). The successful implementation of a radically new sustainability technology requires deep societal changes in different areas (Hollingsworth, 2000; Kemp and Loorbach, 2003; Loorbach and Rotmans, 2006; Van den Bergh et al., 2011).

The following activities can be carried out by entrepreneurs to trigger necessary socio-cultural changes. As underpinned by the strategic management literature, intra-firm changes need to take place. Companies may need to change the way they organize their business activities and introduce a company culture which is predisposed to collaboration (Garud and Kumaraswamy, 1995; Katkalo et al., 2010; Lam, 2004; Ritter and Gemünden, 2003). The norms and values of users need to be changed if they are to accept uncomfortable changes in user behaviour (Andersen and Tukker, 2006; Geels, 2004; Leiserowitz et al., 2006; Schwarz, 2010; Young et al., 2010). Moreover, the educational system needs to be adapted to achieve changes in people's attitudes and to generate a skilled workforce (Freeman, 1995; Jansen, 2003; Kemp and Soete, 1992;

\footnotetext{
${ }^{6}$ When we refer to socio-cultural changes we mean changes in factors such as routines, shared values, norms and trust (cp. Doloreux and Parto, 2004) ingrained in a society, i.e. in the mind-sets of people who live in this society. These changes differ from the changes described in Section 5.2, 'Market creation'. Market creation also comprises changes, but at the level of laws and regulations or marketing activities. Of course, the right socio-cultural changes will have a huge impact on user behaviour and user demand, as well as on the willingness of governmental actors to change regulations. As mentioned earlier and visualized in Fig. 1, the four categories of this framework are highly intertwined and interrelated. Achieving the goals in one category accelerates the achievement of goals in the other categories.
} 
Laszlo, 2003). Furthermore, entrepreneurs mentioned the need to create new types of organizations that can play a facilitating role in the emerging industry and support the long-term collaboration between firms in the industry.

\subsection{Coordination}

The coordination of all system-building efforts accelerates system-building processes. Many actors are involved in system building, each with their own agenda and their own strategic plan. These actors make resources available for system building. The system as a whole benefits most if the resources are combined and efforts are aligned. Without coordination, individual efforts may prove futile. Whereas the system-building categories described above represent system-building goals, the activities clustered in this category function as accelerators and help to speed up systembuilding processes, to achieve system-building goals and to do so more quickly.

Musiolik and Markard argued that coordination along the value chain is a key process for the development of an innovation system (Musiolik and Markard, 2011). Our data showed that this also holds true for the smart grid system and that the entrepreneurs interviewed perceived such coordination as vitally important. However, the analysis of the data indicated that activities aimed at systembuilding coordination go beyond value chain coordination and that more innovation system actors are involved.

The creation of a shared vision towards which the development of the system should move, and the definition of a common goal are both important for the coordination of system-building activities (Harmaakorpi, 2006b; Lambooy, 2004; Quintana-García and Benavides-Velasco, 2004; Schoonhoven et al., 2012; Suurs et al., 2009). The creation of a common goal is more than merely trying to find a compromise of individual company goals. Ideally, systembuilding entrepreneurs should align their company goals towards the achievement of this common goal.

Entrepreneurs also stated that standardization is important to enable the co-development of products and services. Standardization is necessary to build a compatible, reliable new system, in which customers and end-users can easily switch between suppliers or brands. Standardization allows companies along the value chain to simultaneously develop their products and services. While the system is evolving, companies can develop their products and services which will then fit into the new system. Without standardization, too many one-point solutions emerge and the new technology cannot be cost-effective (and hence cannot survive in competition with alternative technologies). An integrated approach is necessary in which actors of the innovation system agree on shared standards. The importance of standardization is stated in the TIS literature (Bergek et al., 2005; Musiolik et al., 2012) as well as in strategic management literature (Pitelis, 2012; Ritala and Hurmelinna-Laukkanen, 2009; Yami and Nemeh, 2014).

To coordinate and accelerate knowledge development and product optimization, the interviewees advised setting up open innovation platforms. These platforms also speed up the codevelopment of complementary products (Chesbrough and Appleyard, 2007; Laszlo, 2003). The activity system orchestration refers to the managing and aligning of individual system-building efforts. Regime change is possible only if many actors collaborate and combine their resources. If they do not align their activities, their individual efforts may prove futile and they may not be able to gain enough leverage to compete with the incumbent technological regime. To manage and connect all individual efforts, a high degree of coordination is necessary. However, this coordination should not be too rigid; if too many rules are set in the formation phase of the new system, the creativity and innovation potential of the system may be hampered.

If a high degree of coordination and system orchestration has been achieved, as well as trust between networking actors, it has been suggested that entrepreneurial managers should think in system-building roles rather than in company objectives. To increase the effects of collective system building, entrepreneurs would need to detach themselves from the primary aim of selling their company's product or service, and instead consider which role they can play in building the new system. In other words, it is the system that is seen as the entity in which a role is to be performed, rather than the individual organization. A balance needs to be found between achieving the company objectives and common system objectives.

A much stated problem for system building regarding smart grids was the huge overlap in research and knowledge diffusion activities such as pilot projects and conferences. This overlap results in redundant activities and therefore inefficient resource use. The creation of transparency of all activities going on in the field helps to reduce such overlap and to avoid the depletion of resources.

\subsection{Validation of results}

After having analysed and discussed the above findings, we validated them in two additional steps (described in detail in Section 3.4). The online survey among our interviewees and among a second group of different entrepreneurs from the smart grid sector revealed that both groups of respondents regard almost all different activities within the category Technology development and optimization as 'important' or 'very important' (between 4 and 5 on a 5-point scale). In addition, it became clear that - only for the interview partners - the co-creation of products and services and the feedback loops with user groups were slightly less important (3.9 and 3.6 on a 5-point scale) than the other activities in this cluster.

With respect to the category Market creation, both groups of respondents rated the activities creation of a temporarily protected niche market and collaborative competition against other technology clusters as the least important activities in this cluster. These activities, however, still score on average at least a 3 (on a 5-point scale), with the exception of the creation of a temporarily protected niche market, which was given an average of 2.3 by the interview partners. One respondent explained that "a protected niche market has the inherent risk of free riding". Someone else stated that temporarily protected niche markets can only be a boundary condition; they cannot make a technology succeed, if the technology does not provide its users with added value. With respect to the category Socio-cultural changes, all activities were indicated as relevant and the average scores for importance were between neutral and important, with an average of 3.3. Only one respondent thought that creating new facilitating organizations was not relevant for system building.

The activities were also clearly considered important for the category Coordination. The analysis revealed that our interviewees rated the importance of the activities for this category between 3.8 and 4.4. For the second group the average scores for the activities ranged between 3.4 and 4.3. In general, these activities are seen as relatively important.

Regarding the overarching categories, we asked the respondents to consider the importance of each category. The results indicate that they found all categories important, although some categories were ranked slightly higher in importance than others. Both groups overall ranked Market creation highest, followed by Technology development and optimization, Coordination and Socio-cultural 
changes. In sum, the outcome of our survey confirmed that the system-building activities described above are necessary and important for collective system building.

The workshop with entrepreneurs from different fields also revealed that the entrepreneurs valued the strategy framework. It also became clear that the framework was applicable for other industries. For example, one participant from the health care sector explained that this framework would also be suitable for her sector. However, she suggested that it might be clearer for her sector to relabel Technology development as Product development, because innovations in the health care sector are not necessarily technological innovations. A participant from the creative industry stated that this also held for his industry. The outcome of the meeting was that participants agreed that the strategy framework would be suitable for their particular industries.

\section{Conclusions and implications}

The objective of this paper was to combine insights from the strategic management literature and the TIS literature in order to provide a strategy framework for entrepreneurs and entrepreneurial managers to collectively build a favourable environment for their sustainability technology. By creating a supportive innovation system or business ecosystem for their new technology, they increase the chances of successful commercialization. A wide diffusion of sustainability technologies, which replace unsustainable technologies, accelerates the transition towards sustainable development. First, we introduced the concept of collective system building and illustrated it with the empirical case of the Dutch smart grid field. Our empirical study shows that the theoretical concept we developed based on literature review actually occurs in the smart grid field. Collective system building takes place, although generally this does not occur in a strategic manner. However, the interviewees confirmed that a more strategic approach to collective system building ('strategic collective system building') would accelerate the diffusion of their new technology. Based on the concept of strategic collective system building we have developed a strategy framework for entrepreneurs and entrepreneurial managers to collectively create a favourable environment for their sustainability technology. We term it 'strategy framework for collective system building'. The strategy framework consists of four key areas for strategy making: technology development and optimization, market creation, socio-cultural changes and coordination (see Fig. 1). Each of these key strategic areas is composed of a set of system-building activities. The first three categories are system-building goals which entrepreneurs collectively strive for. The category 'coordination' comprises all the activities that manage and align system-building efforts, lead to combining forces and resources and thus accelerate the system-building processes. An overview of these categories and system-building activities is presented below in Fig. 2 .

The system-building activities identified in the study were derived from or referred to the TIS literature and the strategic management literature. This underlines the importance of combining these fields of literature. Focusing on only one of these fields would have resulted in an incomplete strategy framework, whereas the combination of these fields of literature results in a comprehensive overview of system-building activities. The system perspective of the TIS literature complements the firm perspective of the strategic management literature, and the combination of both fields acknowledges the interplay between both levels. An overview has been generated of system-building activities that networks of firms can carry out to achieve system level changes.
The strategic management literature so far only described the importance of a supportive external environment, but did not yet provide insights into how to strategically build up such environment. The use of the TIS literature enabled us to make it clearer which processes entrepreneurs need to trigger to influence changes at the system-level, which lead to a more favourable environment in which to implement their innovative technology. Moreover, we contribute to the TIS literature, which has been focused on the system-level and the perspective of policymakers, by introducing to it the firm perspective. Beyond the literature discussed in the theory section, we recognized that additional valuable insights can be gained from the open innovation literature, as some systembuilding activities from the category Coordination are supported by that field of literature.

Our research was based on a single case study, which might be a limitation. However, the framework used was firmly based on extensive literature research and if possible we related our findings to the literature to increase its generalizability. Moreover, we obtained rich empirical data since we spoke to the most important actors in the field and to leading representatives of different actors along the value chain who are driving system building around the smart grid technology in the Netherlands. It is not yet clear how applicable the new strategy framework is for different emerging technologies; after all, not all the system-building activities mentioned in the framework may be equally relevant for different technologies or in different domains. Even though the validation step of our research showed that the strategy framework might be suitable for other industries, it also showed that the focus in some industries may indeed be slightly different. The specific characteristics of a technology or a domain could result in different weighting of the importance of the activities and of activity clusters. In the case of the smart grid technology, for instance, the respondents rated the activities related to coordination as very important. As explained earlier, smart grid technology does not comprise one technology, but a complex set of intertwined technologies. Due to the complexity and interdependency of this new technology, actors know that they need to collaborate and this may explain the importance attributed to coordination. In other cases, for example if there is a great deal of resistance among consumers or if the technology is questionable, other activities from the category Socio-cultural changes may be considered more important. The strategy framework that we developed cannot be considered a one-size-fits-all solution yet. Therefore, a possible next step is the validation of the framework in different technological fields.

With regard to the practical implications of our research, we have reframed system building from a strategic management perspective, and thus provided a framework that entrepreneurs and entrepreneurial managers can use for system building. The framework depicts an overview of activities that firms can undertake in order to build a system. Networks of entrepreneurs can use this framework as a tool to collect and structure information, based on which they can generate strategies for system building. We have facilitated the structuring of information by clustering systembuilding activities according to the underlying system-building goals that these activities contribute to. This framework can also be used by networks of entrepreneurs to facilitate their understanding, not only of the various system-building goals but also of the activities they can carry out to achieve these goals. It might help them to identify activities that firms already focus on enough, as well as activities that have not yet been given sufficient attention and resources. They can use the framework to set goals, divide tasks and distribute roles. Depending on the type of technology, its broader context and the development phase of the emerging field, not all activities may be equally important. This prioritization as 


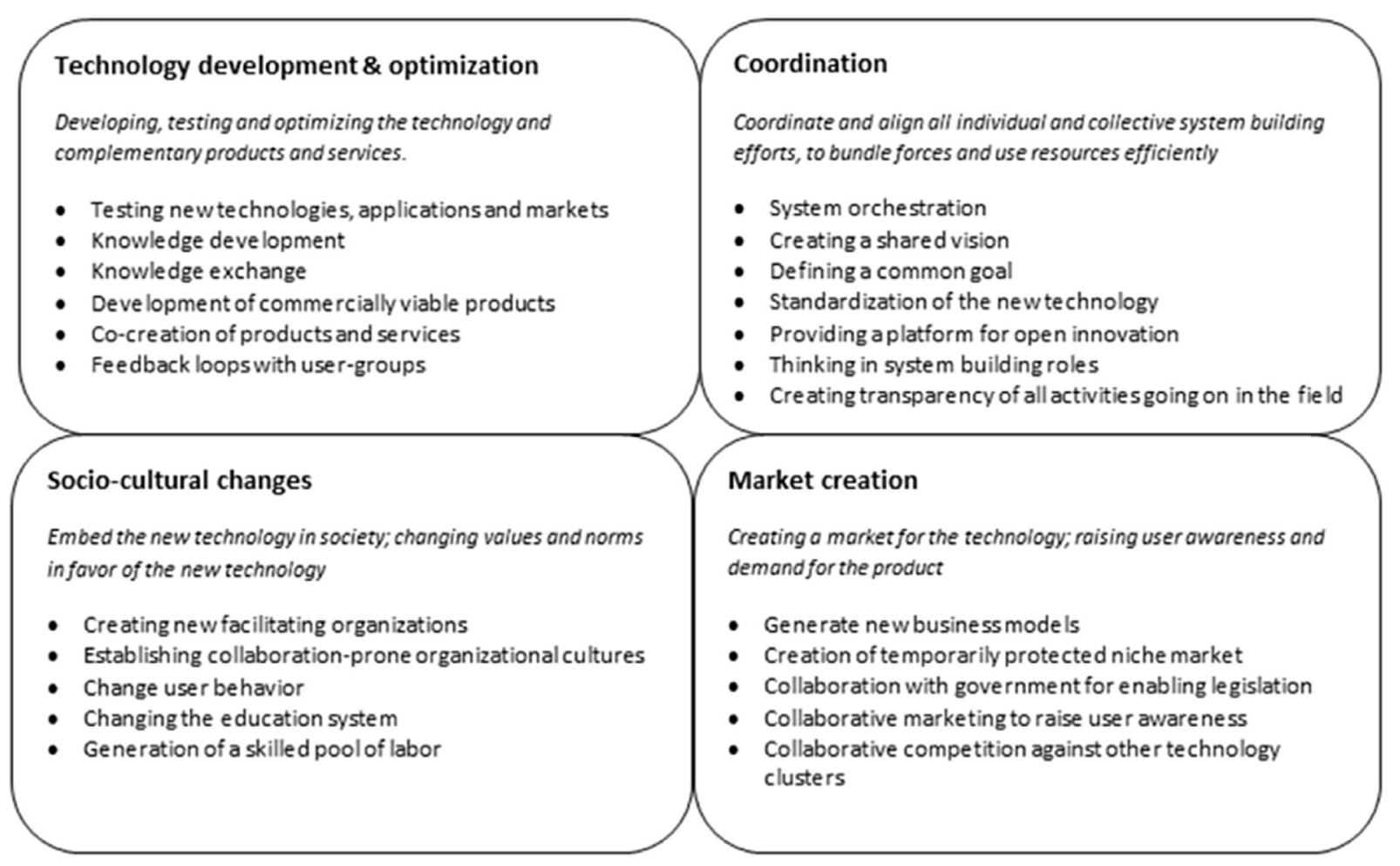

Fig. 2. Overview of the strategy framework for system building and its system-building activities.

well as the task division between network partners has to be undertaken by the practitioners. Moreover, the presentation of system-building activities according to system-building goals facilitates the setting of strategic objectives for practitioners, which helps them to measure and evaluate the outcome of their strategic activities.

\section{References}

Andersen, M.M., Tukker, A., 2006. Perspectives on Radical Changes to Sustainable Consumption and Production. Sustainable Consumption Research Exchange, Copenhagen.

Astley, W.G., 1984. Toward an appreciation of collective strategy. Acad. Manag. Rev. 9, 526-535.

Astley, W.G., Fombrun, C.J., 1983. Collective strategy: social ecology of organizational environments. Acad. Manag. Rev. 8, 576-587.

Bengtsson, M., Kock, S., 2000. "Coopetition” in business Networks-to cooperate and compete simultaneously. Ind. Mark. Manag. 29, 411-426. http://dx.doi.org/ 10.1016/S0019-8501(99)00067-X.

Bergek, A., Jacobsson, S., Carlsson, B., Lindmark, S., 2005. Analyzing the Dynamics and Functionality of Sectoral Innovation System - a Manual (No. 2005-05-09). DRUID conferences, Copenhagen.

Bergek, A., Hekkert, M.P., Jacobsson, S., 2008a. Functions in innovation systems: a framework for analysing energy system dynamics and identifying goals for system-building activities by entrepreneurs. In: Foxton, T., Koehler, J., Oughton, C. (Eds.), Innovations for a Low Carbon Economy: Economic, Institutional and Management Approaches. Edward Elgar Publishing, Cheltenham.

Bergek, A., Jacobsson, S., Carlsson, B., Lindmark, S., Rickne, A., 2008b. Analyzing the functional dynamics of technological innovation systems: a scheme of analysis. Res. Policy 37, 407-429. http://dx.doi.org/10.1016/j.respol.2007.12.003.

Bergek, A., Jacobsson, S., Sandén, B., 2008c. "Legitimation" and "development of positive externalities": two key processes in the formation phase of technological innovation systems. Technol. Anal. Strateg. Manag. 20, 575-592. http:// dx.doi.org/10.1080/09537320802292768.

Caniëls, M.C.J., Romijn, H.A., 2008. Actor networks in strategic niche management: insights from social network theory. Futures 40, 613-629. http://dx.doi.org 10.1016/j.futures.2007.12.005.

Chesbrough, H.W., Appleyard, M.M., 2007. Open innovation and strategy. Calif. Manage. Rev. 50, 57-76.

Cooke, P., 2008. Regional innovation systems, clean technology \& Jacobian clusterplatform policies. Reg. Sci. Policy Pract. 1, 23-45. http://dx.doi.org/10.1111/ j.1757-7802.2008.00002.x.
Davenport, T.H., Leibold, M., Voelpel, S.C., 2007. Strategic Management in the Innovation Economy: Strategic Approaches and Tools for Dynamic Innovation Capabilities. John Wiley \& Sons.

Doloreux, D., Parto, S., 2004. Regional Innovation Systems: a Critical Synthesis (No. 2004-17). United Nations University, Institute for New, United Nations University Discussion Paper Series, Maastricht.

Farla, J., Markard, J., Raven, R., Coenen, L., 2012. Sustainability transitions in the making: a closer look at actors, strategies and resources. Technol. Forecast. Soc. Change 79, 991-998. http://dx.doi.org/10.1016/j.techfore.2012.02.001.

Fischer, C., 2008. Emissions pricing, spillovers, and public investment in environmentally friendly technologies. Energy Econ. 30, 487-502. http://dx.doi.org/ 10.1016/j.eneco.2007.06.001.

Foxon, T., Makuch, Z., Mata, M., Pearson, P., 2004. Innovation systems and policymaking processes for the transition to sustainability. In: Jacob, K., Binder, M., Wieczorek, A. (Eds.), Governance for Industrial Transformation. Proceedings of the 2003 Berlin Conference on the Human Dimensions of Global Environmental Change. Environmental Policy Research Centre, Berlin, pp. 96-112.

Foxon, T., Pearson, P., 2008. Overcoming barriers to innovation and diffusion of cleaner technologies: some features of a sustainable innovation policy regime. J. Clean. Prod. 16, S148-S161. http://dx.doi.org/10.1016/j.jclepro.2007.10.011.

Freeman, C., 1995. The "National System of Innovation" in historical perspective. Camb. J. Econ. 19, 5-24.

Garud, R., Hardy, C., Maguire, S., 2007. Institutional entrepreneurship as embedded agency: an introduction to the special issue. Organ. Stud. 28, 957-969. http:// dx.doi.org/10.1177/0170840607078958.

Garud, R., Kumaraswamy, A., 1995. Technological and organizational designs for realizing economies of substitution. Strateg. Manag. J. 16, 39-109.

Garud, R., Kumaraswamy, A., 1993. Changing competitive dynamics in network industries: an exploration of sun microsystems' open systems strategy. Strateg. Manag. J. 14, 351-369.

Geels, F.W., 2005. Processes and patterns in transitions and system innovations: refining the co-evolutionary multi-level perspective. Trans. Towar. Sustain. Syst. Innov. 72, 681-696. http://dx.doi.org/10.1016/j.techfore.2004.08.014.

Geels, F.W., 2004. From sectoral systems of innovation to socio-technical systems: insights about dynamics and change from sociology and institutional theory. Res. Policy 33, 897-920. http://dx.doi.org/10.1016/j.respol.2004.01.015.

Geels, F.W., 2002. Technological transitions as evolutionary reconfiguration processes: a multi-level perspective and a case-study. Res. Policy 31, 1257-1274. http://dx.doi.org/10.1016/S0048-7333(02)00062-8.

Geels, F.W., Hekkert, M.P., Jacobsson, S., 2008. The dynamics of sustainable innovation journeys. Technol. Anal. Strateg. Manag. 20, 521-536. http://dx.doi.org/ $10.1080 / 09537320802292982$.

Georg, S., 1994. Regulating the environment: changing from constraint to gentle coercion. Bus. Strateg. Environ. 3, 11-20. http://dx.doi.org/10.1002 bse.3280030203. 
Hagedoorn, J., Schakenraad, J., 1994. The effect of strategic technology alliances on company performance. Strateg. Manag. J. 15, 291-309.

Hall, B.H., Khan, B., 2003. Adoption of New Technology (No. E03-330), Other Recent Work. Berkeley, California.

Hall, J., Daneke, G., Lenox, M., 2010. Sustainable development and entrepreneurship: past contributions and future directions. J. Bus. Ventur. 25, 439-448. http://dx.doi.org/10.1016/j.jbusvent.2010.01.002.

Hargadon, A., 2010. Technology policy and global warming: why new innovation models are needed. Res. Policy 39, 1024-1026. http://dx.doi.org/10.1016/ j.respol.2010.05.009.

Harmaakorpi, V., 2006a. Regional Development Platform Method (RDPM) as a Tool for Regional Innovation Policy 114.

Harmaakorpi, V., 2006b. Regional Development Platform Method (RDPM) as a tool for regional innovation policy 1. Eur. Plan. Stud. 14, 1085-1104. http:// dx.doi.org/10.1080/09654310600852399.

Hekkert, M.P., Negro, S.O., 2009. Functions of innovation systems as a framework to understand sustainable technological change: empirical evidence for earlier claims. Technol. Forecast. Soc. Change 76, 584-594. http://dx.doi.org/10.1016/ j.techfore.2008.04.013.

Hekkert, M.P., Suurs, R.A.A., Negro, S.O., Kuhlmann, S., Smits, R.E.H.M., 2007. Functions of innovation systems: a new approach for analysing technological change. Technol. Forecast. Soc. Change 74, 413-432. http://dx.doi.org/10.1016/ j.techfore.2006.03.002.

Hertzog, C., 2013. Re-engineering Energy - a Dutch Perspective [WWW Document], 15-07-2013. URL. http://www.smartgridlibrary.com/2013/07/15/reengineering-energy-a-dutch-perspective/ (accessed 08.14.13.).

Hollingsworth, J.R., 2000. Doing institutional analysis: implications for the study of innovations. Rev. Int. Polit. Econ. 7, 595-644. http://dx.doi.org/10.1080/ 096922900750034563.

Hübner, M., Prüggler, N., 2011. Smart Grid Initiatives in Europe Country Snapshots and Country Fact Sheets. Vienna.

Hughes, T.P., 1987. The evolution of large technical systems. In: Bijker, W.E., Hughes, T.P. (Eds.), The Social Construction of Technical Systems. MIT Press, Cambridge.

Iansiti, M., Levien, R., 2004. Strategy as ecology. Harv. Bus. Rev. 82, 68-81.

Interreg IVB, 2011. Smart Grids and Virtual Power Plants. Lille.

Jacobsson, S., Bergek, A., 2011. Innovation system analyses and sustainability transitions: contributions and suggestions for research. Environ. Innov. Soc. Trans. 1 41-57. http://dx.doi.org/10.1016/j.eist.2011.04.006.

Jacobsson, S., Bergek, A., 2006. A framework for guiding policy-makers intervening in emerging innovation systems in "Catching-Up" countries. Eur. J. Dev. Res. 18, 687-707. http://dx.doi.org/10.1080/09578810601094902.

Jansen, L., 2003. The challenge of sustainable development. J. Clean. Prod. 11, 231-245. http://dx.doi.org/10.1016/S0959-6526(02)00073-2.

Katkalo, V.S., Pitelis, C.N., Teece, D.J., 2010. Introduction: on the nature and scope of dynamic capabilities. Ind. Corp. Chang. 19, 1175-1186. http://dx.doi.org/ 10.1093/icc/dtq026.

Kema, 2012. PowerMatching City Honored as a Top Sustainable Solution at Rio +20 [WWW Document]. URL. www.kema.com/news/articles/2012 (accessed 11.07.12.).

Kemp, R., Loorbach, D., 2003. Governance for sustainability through transition management. In: EAEPE 2003 Conference, Paper for EAEPE 2003 Conference, pp. 1-27. Maastricht.

Kemp, R., Schot, J., Hoogma, R., 1998. Regime shifts to sustainability through processes of niche formation: the approach of strategic niche mangement. Technol. Anal. Strateg. Manag. 10, 175-198. http://dx.doi.org/10.1080/ 09537329808524310.

Kemp, R., Soete, L., 1992. The greening of technological progress: an evolutionary perspective. Futures 24, 437-457.

Knott, P., 2006. A typology of strategy tool applications. Manag. Decis. 44, 1090-1105. http://dx.doi.org/10.1108/00251740610690630.

Kotler, P., Armstrong, G., Wong, V., Saunders, J., 2008. Principles of Marketing, 5th Europe. Prentice Hall.

Laan, M. van der, 2012. Powermatching City Hoogkerk [WWW Document]. URL. http://ict.eu/verticals/energy/customer-cases/powermatching-city-groningenhoogkerk/ (accessed 11.07.12).

Lam, A., 2004. Organizational innovation. In: Fagerberg, J., Movery, D., Nelson, R.R. (Eds.), Handbook of Innovation. Oxford University Press, Oxford.

Lambooy, J.G., 2004. The transmission of knowledge, emerging networks, and the role of universities: an evolutionary approach. Eur. Plan. Stud. 12, 643-657. http://dx.doi.org/10.1080/0965431042000219996.

Laszlo, K.C., 2003. The evolution of business: learning, innovation, and sustainability in the twenty-first century. World Futur. 59, 605-614. http://dx.doi.org/ 10.1080/02604020390242114.

Leiserowitz, A., Kates, R.W., Parris, T.M., 2006. Sustainability values, attitudes, and behaviors: a review of multinational and global trends. Annu. Rev. Environ. Resour. 31, 413-444. http://dx.doi.org/10.1146/annurev.energy.31.102505. 133552.

Loorbach, D., Rotmans, J., 2006. Managing transitions for sustainable development. In: Olsthoorn, X., Wieczorek, A.J. (Eds.), Understanding Industrial Transformation. Springer, Dordrecht.

Markard, J., Truffer, B., 2008a. Technological innovation systems and the multi-level perspective: towards an integrated framework. Res. Policy 37, 596-615. http:// dx.doi.org/10.1016/j.respol.2008.01.004.
Markard, J., Truffer, B., 2008b. Actor-oriented analysis of innovation systems: exploring micro-meso level linkages in the case of stationary fuel cells. Technol. Anal. Strateg. Manag. 20, 443-464. http://dx.doi.org/10.1080/ 09537320802141429.

Mintzberg, H., Lampel, J., Ahlstrand, B., 1998. Strategy Safari: a Guided Tour through the Wilds of Strategic Management. The Free Press, New York.

Moore, J.F., 2005. Business ecosystems and the view from the firm. Antitrust Bull. 51.

Moore, J.F., 1996. The Death of Competition: Leadership and Strategy in the Age of Business Ecosystems. HarperBusiness, New York.

Musiolik, J., Markard, J., 2011. Creating and shaping innovation systems: formal networks in the innovation system for stationary fuel cells in Germany. Energy Policy 39, 1909-1922.

Musiolik, J., Markard, J., Hekkert, M.P., 2012. Networks and network resources in technological innovation systems: towards a conceptual framework for system building. Technol. Forecast. Soc. Change 79, 1032-1048. http://dx.doi.org/ 10.1016/j.techfore.2012.01.003.

Negro, S.O., Hekkert, M.P., Smits, R.E.H.M., 2008. Stimulating renewable energy technologies by innovation policy. Sci. Public Policy 35, 403-416. http:// dx.doi.org/10.3152/030234208X323334.

Nill, J., Kemp, R., 2009. Evolutionary approaches for sustainable innovation policies: from niche to paradigm? Res. Policy 38, 668-680. http://dx.doi.org/10.1016| j.respol.2009.01.011.

NL Agency, 2012a. PowerMatching City II. Utrecht.

NL Agency, 2012b. Smart Grids \& Smart Metering. Utrecht.

NL Agency, 2012c. Who Is Who Guide Players in the Dutch Smart-grid Sector. Utrecht.

O'Connor, M., 1997. The internalisation of environmental costs: implementing the Polluter Pays principle in the European Union. Int. J. Environ. Pollut. 7, 450-482.

Pitelis, C., 2012. Clusters, entrepreneurial ecosystem co-creation, and appropriability: a conceptual framework. Ind. Corp. Chang. 21, 1359-1388. http:// dx.doi.org/10.1093/icc/dts008.

Porter, M.E., 1998. Clusters and the new economics of competition. Harv. Bus. Rev. 76, 77-90.

Porter, M.E., Kramer, M.R., 2011. Creating shared value. Harv. Bus. Rev. 89, 62-77.

Quintana-García, C., Benavides-Velasco, C. a, 2004. Cooperation, competition, and innovative capability: a panel data of European dedicated biotechnology firms. Technovation 24, 927-938. http://dx.doi.org/10.1016/S0166-4972(03) 00060-9.

Ritala, P., Hurmelinna-Laukkanen, P., 2009. What's in it for me? Creating and appropriating value in innovation-related coopetition. Technovation 29, 819-828. http://dx.doi.org/10.1016/j.technovation.2009.07.002.

Ritala, P., Sainio, L.-M., 2014. Coopetition for radical innovation: technology, market and business-model perspectives. Technol. Anal. Strateg. Manag. 26, 115-169. http://dx.doi.org/10.1080/09537325.2013.850476.

Ritter, T., Gemünden, H.G., 2003. Network competence: its impact on innovation success and its antecedents. J. Bus. Res. 56, 745-755. http://dx.doi.org/10.1016/ S0148-2963(01)00259-4.

Rothwell, R., 1991. External networking and innovation in small and medium-sized manufacturing firms in Europe. Technovation 11, 93-112.

Schoonhoven, C.B., Eisenhardt, K.M., Lyman, K., 2012. Speeding Products to Market. In: Waiting Time to First Product Introduction in New Firms Claudia Bird Schoonhoven 35, pp. 177-207.

Schwarz, M., 2010. Social Innovation: Concepts, Research Fields and International Trends. Dortmund.

SEC, 2012. Smart Energy Collective [WWW Document]. Inf. Sheet. http://www. smartenergycollective.com/site/pagina.php?id=44 (accessed 08.14.13.).

Suurs, R.A.A., Hekkert, M.P., 2009. Cumulative causation in the formation of a technological innovation system: the case of biofuels in the Netherlands. Technol. Forecast. Soc. Change 76, 1003-1020. http://dx.doi.org/10.1016/ j.techfore.2009.03.002.

Suurs, R.A.A., Hekkert, M.P., Smits, R.E.H.M., 2009. Understanding the build-up of a technological innovation system around hydrogen and fuel cell technologies. Int. J. Hydrogen Energy 34, 9639-9654. http://dx.doi.org/10.1016/ j.ijhydene.2009.09.092.

Teece, D.J., 2010. Technological innovation and the theory of the firm: the role of enterprise-level knowledge, complementarities, and (dynamic) capabilities. In: Rosenberg, N., Hall, B.H. (Eds.), Handbook of the Economics of Innovation, Handbook of the Economics of Innovation, vol. 1. Elsevier B.V., pp. $679-730$

Van de Ven, A.H., 2005. Running in packs to develop knowledge intensive technologies. MIS Q. 29, 365-378.

Van de Ven, A.H., 1993. The development of an infrastructure for entrepreneurship. J. Bus. Ventur. 8, 212-230.

Van de Ven, A.H., Polley, D.E., Garud, R., Venkataraman, S., 2008a. The Innovation Journey. Oxford University Press, New York.

Van de Ven, A.H., Sapienza, H.J., Villanueva, J., 2008b. Entrepreneurial pursuits of self- and collective interests. Strateg. Entrep. J. 370, 353-370. http://dx.doi.org/ $10.1002 /$ sej.

Van den Bergh, J.C.J.M., Truffer, B., Kallis, G., 2011. Environmental innovation and societal transitions: introduction and overview. Environ. Innov. Soc. Trans. 1, 1-23. http://dx.doi.org/10.1016/j.eist.2011.04.010.

Weaver, P., Jansen, L., Grootveld, G., van, Spiegel, E., van, Vergragt, P., 2000. Sustainable Technology Development. Greanleaf Publishing, Sheffield. 
Wolfe, D.A., Gertler, M.S., 2004. Clusters from the inside and out: local dynamics and global linkages. Urban Stud. 41, 1071-1093. http://dx.doi.org/10.1080/ 00420980410001675832.

Yami, S., Nemeh, A., 2014. Organizing coopetition for innovation: the case of wireless telecommunication sector in Europe. Ind. Mark.
Manag. 43, 250-260. http://dx.doi.org/10.1016/j.indmarman.2013. 11.006.

Young, W., Hwang, K., Mcdonald, S., Oates, C.J., 2010. Sustainable consumption: green consumer behaviour when purchasing products. Sustain. Dev. 18, 20-31. http://dx.doi.org/10.1002/sd.394. 